\title{
KARAKTERISTIK KESULITAN BELAJAR MEMBACA PADA SISWA KELAS RENDAH SEKOLAH DASAR
}

\author{
Fauzi \\ e-mail: fauzi@iainpurwokerto.ac.id \\ Institut Agama Islam Negeri Purwokerto
}

Jalan A. Yani No.40-A, Kabupaten Banyumas, Jawa Tengah 53127

\begin{abstract}
Abstrak: Kajian ini bertujuan untuk menganalisis bentuk dan karakteristik kesulitan belajar membaca siswa kelas rendah sekolah dasar, perbedaan kesulitan belajar membaca yang dialami oleh masingmasing siswa, serta berbagai bentuk atau jenis kesulitan belajar membaca yang paling dominan dihadapi oleh siswa. Penelitian ini dilaksanakan di Sekolah Dasar Negeri 3 Bobosan Kecamatan Purwokerto Utara, Kabupaten Banyumas, Provinsi Jawa Tengah, pada bulan April - Juni 2011. Penelitian dilakukan menggunakan pendekatan kualitatif dengan jenis studi kasus yang bersifat deskriptif. Untuk mengumpulkan data, peneliti menggunakan teknik wawancara, observasi, dokumentasi, dan tes praktik membaca. Data dianalisis dengan teknik analisis deskriptif kualitatif. Hasil kajian menunjukkan bahwa kesulitan belajar membaca yang dihadapi oleh siswa tampil dalam empat bentuk, yakni kebiasaan membaca yang tidak wajar, kekeliruan mengenal kata, kekeliruan memahami bacaan, dan gejala serbaneka. Terdapat perbedaan dan persamaan karakteristik kesulitan belajar membaca yang dihadapi oleh siswa pada beberapa bentuk kesulitan tertentu. Dalam aspek capaian hasil belajar, siswa yang mengalami kesulitan belajar membaca menunjukkan hasil belajar yang rendah pada mata pelajaran-mata pelajaran yang lain. Hal ini berarti bahwa kesulitan belajar membaca berhubungan dengan rendahnya hasil belajar siswa pada mata pelajaran yang lain.
\end{abstract}

Kata-kata kunci: kesulitan belajar, kesulitan belajar membaca, siswa kelas rendah, sekolah dasar

\section{CHARACTERISTICS OF LEARNING DIFFICULTIES IN READING AT THE EARLY GRADE STUDENT OF ELEMENTARY SCHOOL}

\begin{abstract}
This study aims to analyze the shape and characteristics of learning difficulties in reading at the early grade student of primary school; different learning difficulties of reading experienced by each student, as well as various forms or types of learning difficulties read the most dominant faced by students. This research was conducted at Sekolah Dasar Negeri 3 Sekolah Dasar Negeri 3 Bobosan Kecamatan Purwokerto Utara, Kabupaten Banyumas, Provinsi Jawa Tengah, in April - June 2011. The research was conducted using the qualitative approach with descriptive case study type. To collect research data using interview techniques, observation, documentation, and reading practice test. Data were analyzed by qualitative descriptive analysis technique. The results of the study showed that learning difficulties of reading faced by students appear in four forms of unusual reading habits, mistakes to recognize words, misconceptions of reading, and various symptoms. There are differences and similarities in the characteristics of learning difficulties in reading faced by students in certain forms of difficulty. In terms of achievement of learning outcomes, students who have difficulty learning to read show low learning outcomes in other subjects. This means that learning difficulties of reading are associated with low student learning outcomes in other subjects.
\end{abstract}

Keywords: learning difficulty, learning difficulty of reading, early grade student, primary school

\section{PENDAHULUAN}

Dalam semua aktivitas belajar di sekolah, membaca dipandang sebagai aktivitas yang bersifat komplek dan menjadi penentu keberhasilan siswa dalam studinya. Kompleksitas belajar membaca dikarenakan kegiatan membaca berkaitan dan melibatkan berbagai kemampuan dalam mengingat simbol-simbol grafis yang berbentuk huruf, dan mengingat bunyi dari simbol-simbol huruf dalam 
rangkaian kata dan kalimat yang mengandung makna (Jamaris, 2009).

Kemampuan membaca bagi siswa dipandang menjadi penentu keberhasilan dalam aktivitas belajarnya di sekolah, dikarenakan seluruh materi pelajaran dalam berbagai bidang studi yang diajarkan di sekolah menuntut pemahaman akan konsep dan teori yang harus dipahami melalui aktivitas membaca. Dengan kemampuan membaca yang benar dan handal akan menjadi modal dasar dan penentu utama keberhasilan dalam berbagai mata pelajaran; begitupun sebaliknya kegagalan dalam penguasaan kemampuan belajar membaca akan menjadi penghambat atau bahkan akan menjadi salah satu sumber kegagalan dalam studi siswa di sekolah.

Paparan di atas diperkuat dengan berbagai hasil kajian yang telah dilakukan para ahli tentang pentingnya kemampuan membaca dalam aktivitas belajar dan untuk dikuasai oleh siswa semenjak kelas rendah sekolah sadar. Diantaranya hasil kajian yang menginformasikan bahwa kemampuan membaca harus dimiliki oleh semua siswa karena dengan kemampuan membaca yang baik, siswa dapat belajar banyak hal tentang berbagai bidang studi (Abdurrahman, 2003). Dalam konteks implementasi kurikulum di sekolah, kemampuan membaca menjadi unsur utama penentu keberhasilan dalam hal penguasaan sumber belajar atau literatur, dan penguasaan beragam ilmu pengetahuan (Morris, Tyner, \& Perney, 2000).

Terkait dengan pentingnya kemampuan membaca siswa di kelas rendah Sekolah Dasar (SD) dan Madrasah Ibtidaiyah (MI), belajar membaca menjadi salah satu kompetensi belajar pokok yang menjadi menu utama pembelajaran selain menulis dan berhitung (Sandjaja, 1993). Belajar membaca menjadi pelajaran khusus selama tahun-tahun awal sekolah dasar (Santrock, 1999). Studi yang dilakukan Morris, Tyner, \& Perney (2000) menunjukkan bahwa kemampuan membaca menjadi fondasi dasar dalam penguasaan berbagai bidang studi.

Kemampuan membaca lancar secara eksplisit sudah mulai dituntut dikuasai anak ketika berada di kelas 2 sekolah dasar. Hal ini dapat dilihat pada Kompetensi Dasar (KD) kurikulum 2013 yang diatur dalam Permendikbud Nomor 24 Tahun 2016 tentang Kompetensi Inti dan Kompetensi Dasar Pelajaran pada Kurikulum 2013 pada Pendidikan Dasar dan Pendidikan Menengah. Pada kelas 2 diantaranya disebutkan pada KD 3.5 berbunyi, "Mencermati puisi anak dalam bahasa Indonesia atau bahasa daerah melalui teks tulis dan lisan". Kompetensi mencermati puisi yang tertulis dalam teks tulis sebagaimana dalam KD tersebut tentu saja memerlukan prasyarat kemampuan membaca yang dimiliki oleh siswa. Selanjutnya pada KD 3.7 berbunyi, "Mencermati tulisan tegak bersambung dalam cerita dengan memperhatikan penggunaan huruf kapital (awal kalimat, nama bulan dan hari, dan nama orang) serta mengenal tanda titik pada kalimat berita dan tanda tanya pada kalimat tanya". Pada KD 3.7 ini secara lebih tegas disebutkan kemampuan "mencermati tulisan". Mencermati tulisan dengan memperhatikan berbagai penggunaan huruf dan tanda tulis tentulah memerlukan kemampuan membaca yang memadai. Demikian halnya pada KD 4.5 yang berbunyi, "Membacakan teks puisi anak tentang alam dan lingkungan dalam bahasa Indonesia dengan lafal, intonasi, dan ekspresi yang tepat sebagai bentuk ungkapan diri". Dalam KD 4.5. bahkan lebih eksplisit tertulis kompetensi membacakan teks puisi dengan lafal dan intonasi yang tepat, bahkan dengan intonasi ekspresi diri yang sesuai dengan isi teks yang dibaca (Kemdikbud, 2016).

Kemampuan membaca lancar yang mulai dituntut dikuasai anak pada kelas 2 sebagaimana paparan di atas tentunya masih bersifat proses (on going process). Hal ini dapat dilihat dari kebijakan adanya Tes Kemampuan Dasar (TKD) membaca, menulis, dan berhitung bagi siswa SD dilakukan pada akhir kelas 3. Pada Kepmendiknas Nomor 012/U/2002 pasal 12 berbunyi, “(1) tes kemampuan dasar dilakukan untuk mengetahui kemampuan membaca, menulis, dan berhitung yang diperlukan dalam rangka memperbaiki program pembelajaran (program remedial); (2) tes kemampuan dasar dilakukan setiap tahun pada akhir kelas 3" (Depdiknas, 2002).

Paparan singkat KD kelas 2 terkait dengan kompetensi membaca yang harus dikuasai anak dan kebijakan TKD sebagaimana uraian-uraian di atas memiliki konsekuensi (1) pada saat anak berada di kelas 2 harus diupayakan proses pembelajaran membaca dengan strategi yang tepat agar anak dapat memiliki kemampuan membaca yang memadai; (2) guru kelas 2 juga harus secara kontinu melakukan analisis dan deteksi dini atas kesulitan belajar membaca yang dihadapi siswa untuk dijadikan dasar melakukan treatment yang tepat guna mengatasi kesulitan tersebut; (3) kemampuan membaca lancar harus benar-benar sudah dikuasai anak SD pada akhir kelas 3, sehingga pada saat anak memasuki kelas 4, sudah tidak menghadapi kesulitan dalam belajar yang disebabkan karena kemampuan membacanya; 
(4) jika sampai akhir kelas 3, masih ditemukan siswa yang hasil TKD membacanya belum sesuai standar kemampuan dasar yang distandarkan harus segera dilakukan remedial.

Kajian-kajian di atas menegaskan bahwa jika seorang siswa di kelas-kelas rendah sekolah dasar tidak segera memiliki kemampuan membaca, maka dipastikan akan mengalami banyak kesulitan dalam mempelajari berbagai bidang studi pada kelaskelas berikutnya. Dalam kenyataan di lapangan, ditemukan masih banyaknya siswa kelas rendah sekolah dasar yang belum memiliki kemampuan membaca dengan baik dan benar. Hal ini dibuktikan dengan hasil uji kompetensi dasar membaca, menulis, dan berhitung pada kelas rendah sekolah dasar masih ditemukan anak-anak yang capaian kemampuan membacanya belum mencapai standar dan masih mengalami kesulitan belajar membaca dengan kondisi kemampuan membaca yang sangat tidak memuaskan.

Menurut Delphie (2006), dalam proses pendidikan di lembaga pendidikan formal, anak berkesulitan belajar membaca banyak ditemui di SD reguler dengan hasil belajar rendah sehingga keberadaannya sering dianggap sebagai siswa yang berprestasi rendah (underachievers), terutama di kelas 1, 2, dan 3 yang disebut kelas rendah, dengan jumlah diperkirakan kisaran antara 2 - 10\% (Somad, 2002).

Berdasarkan hasil kajian sebelumnya, ditemukan informasi bahwa kesulitan belajar membaca sebagai jenis kesulitan belajar yang paling banyak dihadapi siswa SD kelas awal atau kelas rendah. Terdapat sekitar $85 \%$ siswa kelas awal SD yang diidentifikasi mengalami kesulitan belajar, memiliki masalah utama yang berhubungan dengan membaca dan kemampuan bahasa (Jamaris, 2009). Hal tersebut menunjukkan bahwa terdapat problem serius yang dihadapi dunia pendidikan di sekolah dasar berupa banyaknya kesulitan belajar membaca yang dihadapi para siswa. Anak disleksia banyak ditemui di sekolah reguler dan seringkali sepintas tidak mudah untuk dilihat dan dikenali, sehingga diperlukan kajian untuk mengidentifikasi secara akurat akan kondisi yang sebenarnya dihadapi oleh para siswa sebagai dasar untuk mengatasinya dengan tepat.

Siswa yang mengalami kesulitan belajar membaca diidentifikasi mengalami kesulitan belajar membaca huruf, kata atau kalimat yang bukan diakibatkan oleh kasus-kasus utama seperti terbelakang mental, rendahnya visual dan pendengaran, kelainan gerak serta gangguan emosional. Kesulitan membaca itu berkenaan dengan (1) kebiasaan membaca, (2) kekeliruan mengenal kata, (3) kekeliruan pemahaman, dan (4) gejala serbaneka (Mercer dalam Abdurrahman, 2003).

Karakteristik kesulitan belajar membaca yang berkaitan dengan kebiasaan membaca yang tidak wajar berupa gerakan yang penuh ketegangan, seperti mengernyitkan kening, gelisah, irama suara meninggi, atau menggigit bibir. Di samping itu, juga memperlihatkan perilaku menolak untuk membaca, menangis, atau mencoba melawan guru. Karakteristik lainnya berupa pengulangan atau ada baris yang terlompati tidak terbaca, gerakan kepala ke kiri atau ke kanan, kadang-kadang meletakkan kepala pada buku, dan jarak membaca yang kurang dari 37,5 cm (Abdurrahman, 2003).

Untuk karakteristik kekeliruan mengenal kata mencakup penghilangan, penyisipan, penggantian, pembalikan, salah ucap, pengubahan tempat, tidak mengenal kata, dan tersentak-sentak. Gejala kekeliruan memahami bacaan berupa banyak kekeliruan dalam menjawab pertanyaan terkait bacaan, tidak dapat mengemukakan urutan cerita yang dibaca, serta tidak mampu memahami tema utama dari suatu cerita. Adapun karakteristik serbaneka berupa membaca kata demi kata, membaca dengan penuh ketegangan dan nada tinggi, dan membaca dengan penekanan yang tidak tepat (Abdurrahman, 2003).

Berdasarkan paparan-paparan di atas, bahwa penting dilakukan kajian tentang kesulitan belajar membaca yang dihadapi oleh siswa kelas rendah sekolah dasar. Kajian ini dimaksudkan untuk identifikasi dini terhadap kesulitan siswa dalam belajar membaca. Hal ini penting dilakukan mengingat jika siswa yang mengalami kesulitan belajar membaca tidak dilakukan identifikasi secara akurat tidak akan terungkap kondisi sebenarnya yang berakibat pada ketidaktepatan penanganan yang dilakukan atau bahkan akan terus dibiarkan. Dengan adanya informasi hasil identifikasi yang akurat tentang hal-hal yang terkait dengan kesulitan membaca diharapkan dapat dijadikan acuan bagi guru dan pihak-pihak terkait untuk memberikan intervensi dini guna mengatasi kesulitan-kesulitan belajar membaca yang dihadapi oleh siswa dengan tepat sasaran.

Kajian ini secara operasional bertujuan mendiagnosis atau mengidentifikasi bentuk-bentuk atau jenis kesulitan belajar yang dihadapi oleh siswa yang mengalami kesulitan belajar membaca. Secara khusus, penelitian ini bertujuan mengetahui 
karakteristik kesulitan belajar membaca yang dialami oleh masing-masing siswa yang mengalami kesulitan belajar membaca; perbedaan kesulitan belajar membaca yang dialami oleh masing-masing siswa, serta berbagai bentuk atau jenis kesulitan belajar membaca yang paling dominan dihadapi oleh siswa.

\section{METODE PENELITIAN}

Penelitian ini dilaksanakan di Sekolah Dasar Negeri 3 Bobosan yang beralamat di Jl. Gunung Slamet No. 29, Kelurahan Bobosan, Kecamatan Purwokerto Utara, Kabupaten Banyumas, Provinsi Jawa Tengah. Adapun waktu penelitian dilaksanakan pada bulan April - Juni 2016.

Penelitian dilakukan menggunakan pendekatan kualitatif dengan jenis studi kasus yang bersifat deskriptif (Moleong, 1991). Penelitian diarahkan untuk mendeskripsikan kesulitan-kesulitan belajar membaca yang dihadapi oleh siswa kelas rendah dengan fokus pada kelas II semester genap tahun pelajaran 20152016.

Dalam pengumpulan data, peneliti menggunakan teknik wawancara, observasi, dokumentasi, dan tes praktik membaca. Peneliti melakukan wawancara dengan guru kelas II SD untuk mendapatkan informasi umum terkait siswa yang mengalami kesulitan belajar membaca. Diperoleh informasi ada sekitar enam siswa yang dipandang masih mengalami kesulitan dalam belajar membaca.

Teknik observasi dilakukan terhadap dua sasaran yaitu observasi di kelas dan observasi khusus kepada anak yang menjadi subjek penelitian. Observasi kelas dilakukan langsung ke dalam kelas pada saat pembelajaran berlangsung. Pengamatan di kelas diarahkan untuk mendapatkan informasi terkait aktivitas belajar membaca yang dihadapi oleh siswa sebagai subjek penelitian yang diidentifikasi mengalami kesulitan belajar membaca berdasarkan data hasil belajar dan informasi awal dari guru kelas. Observasi ini diarahkan untuk memastikan informasi guru tentang keberadaaan anak yang mengalami kesulitan belajar sekaligus mendapatkan informasi awal untuk menentukan siswa yang nantinya akan ditetapkan sebagi fokus riset/observasi. Dari hasil observasi secara berturut-turut selama tiga hari (senin, selasa, dan sabtu) diperoleh gambaran awal ada enam siswa yang mengalami kesulitan belajar membaca yaitu FS, WDP, IAW, EN, NS, dan AR. Adapun observasi khusus, peneliti lakukan kepada enam siswa tersebut untuk menemukan siswa yang dapat dipastikan sebagai subjek riset dengan kategori kesulitan belajar membaca paling nampak/menonjol di antara 6 anak tersebut.

Metode dokumentasi digunakan untuk mendapatkan data atau informasi dari buku induk siswa dan dokumentasi nilai hasil belajar/rapor siswa yang mengalami kesulitan belajar membaca. Informasi yang digali dari raport terkait latar belakang atau riwayat hidup siswa yang mengalami kesulitan belajar. Dokumen lain yang digali berupa hasil penilaian membaca yang dilakukan guru kelas, dan diperoleh gambaran awal, ada enam siswa yang mengalami kesulitan belajar membaca, yaitu FS, WDP, IAW, EN, NS, dan AR.

Dari informasi dan data awal tentang siswa yang mengalami kesulitan belajar membaca sebagaimana paparan di atas, selanjutnya ditetapkan tiga anak sebagai subjek riset. Berdasarkan hasil pengamatan khusus, peneliti menetapkan FS, WDP, dan IAW sebagai siswa yang dijadikan subjek riset untuk mendapatkan data tentang kesulitan-kesulitan belajar membaca. Ketiga anak ini dipilih dengan pertimbangan berdasarkan observasi khusus, ketiga anak tersebut dikategorikan sebagai yang mengalami kesulitan belajar membaca paling nampak/menonjol dibandingkan tiga anak yang lain.

Selanjutnya untuk mendapatkan informasi yang mendalam terkait kesulitan-kesulitan yang dihadapi oleh setiap siswa yang menjadi subjek penelitian, dilakukan observasi khusus secara individual dan tes praktik membaca kepada siswa-siswa yang mengalami kesulitan belajar membaca di luar kelas pembelajaran. Observasi individual inilah yang digunakan peneliti untuk mengidentifikasi kesulitan-kesulitan belajar membaca yang dihadapi oleh masing-masing anak. Observasi khusus dilakukan bersamaan dengan aktivitas tes praktik membaca untuk menemukan kesulitan belajar membaca yang dihadapi oleh ketiga siswa tersebut. Dalam kegiatan pengumpulan data ini, berpedoman pada pedoman observasi berupa checklist yang telah disiapkan. Data yang diperoleh dengan observasi menggunakan checklist dijadikan sebagai data utama dalam penelitian ini.

Teknik analisis data dilakukan dengan teknik analisis deskriptif kualitatif dengan langkah-langkah mencatat hasil observasi, wawancara, dan studi dokumentasi yang telah diperoleh; data yang telah diperoleh diklasifikasikan; menganalisis data-data yang terkumpul dan mengidentifikasi sesuai dengan permasalahan yang ditemukan; serta menyimpulkan hasil data yang telah dianalisis dan selanjutnya disajikan dalam bentuk deskripsi. 


\section{HASIL DAN PEMBAHASAN}

Hasil

\section{Identitas siswa yang mengalami kesulitan belajar membaca}

Siswa yang mengalami kesulitan belajar membaca yang menjadi fokus riset ini berjumlah tiga anak yaitu FS, WDP, dan IAW. Ketiga siswa tersebut berada di kelas II SD dengan latar belakang kehidupan keluarga yang berbeda-beda. FS berjenis kelamin laki-laki, berusia 9 tahun, pekerjaan ayahnya sebagai buruh, pekerjaan ibunya sebagai pembantu rumah tangga (yang dalam masyarakat tempat tinggalnya disebut "rewang"), dan pendidikan terakhir kedua orang tuanya sekolah dasar, sedangkan WDP berjenis kelamin perempuan, berusia 9 tahun, pekerjaan ayahnya sebagai buruh, pekerjaan ibunya sebagai ibu rumah tangga (tidak menjalani pekerjaan khusus di luar rumah), dan pendidikan terakhir kedua orang tuanya sekolah dasar. Adapun IAW berjenis kelamin laki-laki, berusia 8 tahun, pekerjaan ayahnya sebagai pedagang, pekerjaan ibunya sebagai ibu rumah tangga (tidak menjalani pekerjaan khusus di luar rumah), pendidikan terakhir ayahnya SMP dan pendidikan terakhir ibunya sekolah dasar.

\section{Keadaan hasil belajar}

FS, berdasarkan data hasil belajar yang tercantum dalam laporan hasil belajar/rapor diperoleh informasi bahwa hasil belajar FS pada kelas I semester 1 (tahun pelajaran 2013/2014) berada pada posisi di bawah rata-rata kelas bahkan hampir semua nilai yang diperoleh berada di bawah Kriteria Ketuntasan Minimal (KKM). Dari sembilan mata pelajaran di kelas I SD hanya ada dua mata pelajaran yang mencapai KKM yaitu mata pelajaran Seni Budaya dan Keterampilan, dan Pendidikan Jasmani, Olahraga dan Kesehatan.

Pada kelas I semester 2 mengalami peningkatan terutama pada pencapaian KKM, dimana hanya ada dua mata pelajaran yang tidak mencapai KKM yaitu mata pelajaran Matematika dan Bahasa Jawa. Namun, pada tingkat rata-rata kelas masih berada jauh di bawah nilai rata-rata kelas. Dengan peningkatan nilai pada semester 2 ini mengantarkannya untuk dapat naik ke kelas II.

Pada kelas II semester 1 tahun pelajaran 2014/2015, nilai hasil belajar menunjukkan penurunan dibandingkan dengan hasil belajar pada kelas I. Dari sembilan mata pelajaran ada empat mata pelajaran yang tidak mencapai KKM yaitu Bahasa Indonesia, Matematika, IPS, dan Bahasa Jawa. Pada kelas II semester 2, hasil belajar yang diperoleh juga menunjukkan hasil yang tidak jauh berbeda, yaitu ada empat mata pelajaran yang juga tidak mencapai KKM. Dengan hasil belajar seperti ini, pada kelas II tahun pelajaran 2014/2015, FS tidak berhasil naik kelas atau tetap tinggal di kelas II sehingga pada saat penelitian ini dilaksanakan, yang bersangkutan berada pada tahun ke dua duduk di bangku kelas II dan sedang berada di semester 2. Untuk hasil belajar pada kelas II semester 1 tahun pelajaran 2015/2016 masih ada tiga mata pelajaran yang tidak mencapai KKM.

Hasil belajar kelas II semester 2 menunjukkan penurunan secara kumulatif dibandingkan hasil belajar pada semester 1. Meskipun demikian, FS naik ke kelas III mengingat dari sisi KKM hanya ada dua mata pelajaran yang tidak mencapai KKM. Menurut informasi yang disampaikan oleh guru kelas, jika nilai yang tidak memenuhi KKM tidak sampai empat mata pelajaran, masih ditoleransi untuk dapat naik kelas.

Jika hasil belajar sebagaimana di atas dikaitkan dengan penilaian kualitatif oleh guru sebagaimana dapat dilihat dalam catatan guru dalam rapor, maka memiliki kesesuaian. Adapun catatan saran yang diberikan guru pada setiap semesternya adalah "Untuk belajar dan berlatih membaca". Artinya bahwa hal penting yang ditekankan oleh guru untuk senantiasa diperhatikan terkait dengan dorongan untuk terus belajar meningkatkan kemampuan membaca. Ini menandakan bahwa FS benar-benar mengalami kesulitan dalam membaca.

Berdasarkan data/informasi sebagaimana uraian di atas, menunjukkan bahwa FS mengalami kesulitan belajar membaca dengan capaian hasil belajar yang rendah.

WDP, berdasarkan data hasil belajar yang tersaji dalam rapor, pada kelas I semester 1 (tahun pelajaran 2013/2014) WDP berada pada posisi di bawah rata-rata kelas bahkan hampir semua nilai yang diperoleh berada di bawah KKM, hanya ada dua mata pelajaran yang mencapai KKM dari sembilan mata pelajaran yang ada. Pada kelas I semester 2 mengalami penurunan pencapaian hasil belajar. Dengan pencapaian hasil yang tidak memenuhi ketentuan/ kriteria, pada kelas I tahun pelajaran 2008/ 2009 tidak naik ke kelas II/tinggal di kelas I.

Untuk pencapaian hasil belajar pada kelas I (mengulang) di tahun pelajaran 2014/2015, baik pada semester gasal maupun genap terjadi peningkatan hasil belajar yang sangat signifikan. Di mana seluruh mata pelajaran dapat mencapai KKM, sehingga pada akhir tahun pelajaran 2014/2015 naik ke kelas II. Meskipun demikian pada kolom catatan, guru masih memberikan catatan agar lebih giat belajar membaca. 
Adapun hasil belajar pada kelas II semester 1 pada tahun pelajaran 2015/2016 menunjukkan hasil pencapaian KKM untuk semua mata pelajaran. Namun pada sisi pencapaian kemampuan membaca nampaknya guru masih memberikan catatan untuk "Berlatih terus dalam membaca dan menulis". Catatancatatan tersebut menggambarkan bahwa WDP masih menghadapi problem membaca, sedangkan hasil belajar kelas II semester 2 menunjukkan penurunan secara kumulatif dibandingkan hasil belajar pada semester 1 . Meskipun demikian, WDP naik ke kelas III mengingat dari sisi KKM seluruh mata pelajaran dapat mencapai KKM.

IAW, berdasarkan data hasil belajar yang tersaji di dalam rapor, pada kelas I semester 1 dan semester 2 (tahun pelajaran 2013/2014), IAW berada pada posisi di bawah rata-rata kelas dan hampir semua nilai yang diperoleh berada di bawah KKM, hanya ada dua mata pelajaran yang mencapai KKM dari sembilan mata pelajaran. Dengan pencapaian hasil yang tidak memenuhi ketentuan ini, maka pada kelas I tahun pelajaran 2013/2014 tidak naik ke kelas II/ tinggal di kelas I.

Untuk pencapaian hasil belajar pada kelas I (mengulang) di tahun pelajaran 2014/2015, baik pada semester gasal maupun genap terjadi peningkatan hasil belajar yang sangat signifikan. Pada semester 1 hanya ada dua mata pelajaran yang tidak mencapai KKM dan untuk semester 2, seluruh mata pelajaran dapat mencapai KKM, sehingga pada akhir tahun pelajaran 2014/2015 IAW naik ke kelas II. Meskipun demikian pada kolom catatan, guru masih memberikan catatan agar belajar membaca.

Adapun hasil belajar pada kelas II semester 1 pada tahun pelajaran 2015/2016 menunjukkan hasil pencapaian KKM untuk semua mata pelajaran. Namun pada sisi pencapaian kemampuan membaca nampaknya guru masih memberikan catatan untuk "Berlatih terus dalam membaca dan menulis". Catatan yang menggambarkan bahwa IAW masih menghadapi problem membaca.

Untuk semester 2 terjadi penurunan hasil belajar, dari sembilan mata pelajaran, empat mata pelajaran diantaranya tidak mencapai KKM, dan untuk kenaikan kelas tahun pelajaran 2015/2016, IAW dinyatakan tinggal kelas/tidak naik ke kelas III. Sebagaimana pada kelas I, di kelas II inipun IAW kembali harus mengulang/tidak naik ke kelas III. Di samping hasil belajar yang diperoleh menunjukkan hasil yang rendah, secara kualitatif pada setiap semester, guru memberikan catatan untuk terus belajar membaca. Hal ini menjadi bukti bahwa IAW mengalami problem pada belajar membaca.

\section{Bentuk dan karakteristik kesulitan belajar membaca}

Kesulitan belajar membaca yang dialami

oleh FS, dilihat dari berbagai aspek diantaranya (1) aspek kebiasaan dalam membaca, berdasarkan hasil observasi, FS sangat sering menampilkan kebiasaan membaca yang tidak wajar sebagai penanda tengah mengalami kesulitan belajar membaca. Kebiasaan membaca yang tidak wajar yang ditampilkan FS dapat terkategorikan sebagai berikut (a) kategori sangat sering, dari 12 indikator kebiasaan membaca yang tidak wajar, ada sembilan indikator yang sangat sering ditampilkan oleh FS. Kesembilan indikator yang sangat sering ditampilkan FS pada saat belajar membaca adalah mengernyitkan kening, gelisah, irama suara meninggi, menggigit bibir, terjadi pengulangan dalam membaca, ada baris yang terlompat/tidak dibaca, menggerakkan kepala ke kiri dan ke kanan, meletakkan kepalanya pada buku, dan jarak antara buku dan mata sangat dekat (kurang dari 37,5 cm); (b) kategori sering, untuk kategori kebiasaan membaca yang sering namun tidak sampai sangat sering ada satu indikator yang ditampilkan yaitu menangis ketika diminta membaca; (c) kategori jarang. Dari indikator yang ada, menangis ketika diminta membaca merupakan kebiasaan yang jarang ditampilkan oleh FS; dan (d) kategori tidak pernah. Adapun untuk indikator melawan guru ketika diminta membaca, FS tidak pernah menampilkan indikator ini. Artinya bahwa FS tidak pernah melawan guru ketika harus membaca, meskipun mengalami masalah dalam hal kemampuan membacanya; (2) aspek kekeliruan mengenal kata. Berdasarkan hasil observasi diperoleh informasi bahwa delapan indikator dalam aspek/ dimensi kekeliruan mengenal kata semua ditampilkan oleh FS. Artinya bahwa FS mengalami kesulitan belajar membaca yang diwujudkan dengan kekeliruan mengenal kata dalam semua indikator.

Kedelapan indikator kekeliruan mengenal kata yang ditampilkan oleh FS ketika belajar membaca adalah penghilangan kata, penyisipan, penggantian, pembalikan, salah ucap, pengubahan tempat, gejala keraguan, dan tersentak-sentak; serta (3) aspek kekeliruan memahami bacaan. Berdasarkan hasil observasi diperoleh informasi bahwa tiga indikator dalam aspek/dimensi kekeliruan memahami bacaan semua ditampilkan oleh FS. Artinya bahwa FS mengalami kesulitan belajar membaca yang diwujudkan dengan kekeliruan memahami bacaan dalam semua indikator. Tiga indikator kekeliruan memahami bacaan yang ditampilkan oleh FS ketika belajar membaca adalah banyak keliru menjawab 
pertanyaan dari bacaan, tidak dapat mengemukakan urutan cerita yang dibaca, serta tidak paham tema utama dari cerita isi bacaan; dan (4) aspek gejala serbaneka. Berdasarkan hasil observasi diperoleh informasi bahwa tiga indikator dalam aspek/dimensi serbaneka semua ditampilkan oleh FS. Artinya bahwa FS mengalami kesulitan belajar membaca yang diwujudkan dengan kekeliruan serbaneka dalam semua indikator. Tiga indikator serbaneka yang ditampilkan oleh FS ketika belajar membaca adalah membaca kata demi kata, membaca dengan penuh ketegangan dan nada tinggi, dan membaca dengan penekanan yang tidak tepat.

Kesulitan belajar membaca yang dialami oleh WDP dilihat dari berbagai aspek yang meliputi (1) aspek kebiasaan dalam membaca. Berdasarkan hasil observasi, dalam hal kebiasaan dalam membaca yang tidak wajar, WDP menampilkan beberapa indikator dapat terkategorikan sebagai berikut (a) k a t e g o r i sangat sering. Dari 12 indikator kebiasaan membaca yang tidak wajar, ada tiga indikator yang sangat sering ditampilkan oleh WDP, yaitu terjadi pengulangan dalam membaca, ada baris yang terlompat/tidak dibaca, dan menggerakkan kepala ke arah lateral ke kiri atau ke kanan; (b) kategori sering. Dalam kategori ini ada tiga indikator yang ditampilkan yaitu mengernyitkan kening, irama suara meninggi, dan jarak antara mata dan buku kurang dari 37,5 cm; (c) kategori kadang-kadang. Kategori ini juga ada tiga indikator yang ditampilkan yaitu gelisah, menolak untuk membaca, dan meletakkan kepalanya pada buku; (d) kategori jarang. Menggigit bibir pada saat belajar membaca merupakan indikator kebiasaan yang jarang ditampilkan oleh WDP; dan (e) kategori tidak pernah. Adapun untuk indikator menangis ketika diminta membaca dan indikator melawan guru ketika diminta membaca, WDP tidak pernah menampilkan dua indikator ini. Artinya bahwa WDP tidak pernah menangis dan tidak pernah melawan guru ketika diminta membaca, meskipun mengalami masalah dalam hal kemampuan membacanya; (2) aspek kekeliruan mengenal kata. Berdasarkan hasil observasi, diperoleh informasi bahwa dari delapan indikator dalam aspek/dimensi kekeliruan mengenal kata, ada enam indikator yang ditampilkan oleh WDP, yaitu penghilangan kata, penyisipan, penggantian, salah ucap, gejala keraguan, dan tersentak-sentak, sedangkan dua indikator kekeliruan mengenal kata yang tidak ditampilkan oleh WDP, yaitu pembalikan dan pengubahan tempat; (3) aspek kekeliruan memahami bacaan. Berdasarkan hasil observasi diperoleh informasi bahwa tiga indikator dalam aspek/dimensi kekeliruan memahami bacaan semua ditampilkan oleh WDP. Artinya bahwa WDP mengalami kesulitan belajar membaca yang diwujudkan dengan kekeliruan memahami bacaan dalam semua indikator. Tiga indikator kekeliruan memahami bacaan yang ditampilkan oleh WDP sebagaimana ditampilkan oleh FS ketika belajar membaca adalah banyak keliru menjawab pertanyaan dari bacaan, tidak dapat mengemukakan urutan cerita yang dibaca, serta tidak paham tema utama dari cerita isi bacaan; dan (4) aspek gejala serbaneka. Berdasarkan hasil observasi diperoleh informasi bahwa tiga indikator dalam aspek/dimensi serbaneka semua ditampilkan oleh WDP. Artinya bahwa WDP mengalami kesulitan belajar membaca yang diwujudkan dengan kekeliruan serbaneka dalam semua indikator. Tiga indikator serbaneka yang ditampilkan oleh WDP sebagaimana juga ditampilkan oleh FS ketika belajar membaca adalah membaca kata demi kata, membaca dengan penuh ketegangan dan nada tinggi, dan membaca dengan penekanan yang tidak tepat.

Kesulitan belajar membaca yang dialami oleh IAW dilihat dari berbagai aspek yaitu (1) aspek kebiasaan dalam membaca. Berdasarkan hasil observasi, dalam hal kebiasaan dalam membaca yang tidak wajar, IAW menampilkan beberapa indikator yang dapat terkategorikan sebagai berikut (a) kategori sangat sering. Dari 12 indikator kebiasaan membaca yang tidak wajar, ada tiga indikator yang sangat sering ditampilkan oleh IAW, yaitu irama suara meninggi, terjadi pengulangan dalam membaca, dan meletakkan kepalanya pada buku; (b) kategori sering. Dalam kategori ini ada empat indikator yang ditampilkan yaitu mengernyitkan kening, menggigit bibir, menggerakkan kepala ke arah lateral ke kiri atau ke kanan, dan jarak antara mata dan buku kurang dari 37,5 cm; serta (c) kategori kadang-kadang. Untuk kategori ini juga ada dua indikator yang ditampilkan yaitu gelisah dan ada baris yang terlompat/tidak dibaca; (d) kategori jarang. Menolak untuk membaca pada saat belajar membaca merupakan indikator kebiasaan yang jarang ditampilkan oleh IAW; dan (e) kategori tidak pernah. Adapun untuk indikator menangis ketika diminta membaca dan melawan guru ketika diminta membaca, IAW tidak pernah menampilkan dua indikator ini sama seperti apa yang terjadi pada WDP. Artinya bahwa IAW tidak pernah menangis ketika diminta membaca dan tidak pernah melawan guru ketika harus membaca, meskipun mengalami masalah dalam hal kemampuan membacanya; (2) aspek kekeliruan mengenal kata. 
Berdasarkan hasil observasi, diperoleh informasi bahwa dari delapan indikator dalam aspek/dimensi kekeliruan mengenal kata, ada lima indikator yang ditampilkan oleh IAW, yaitu penghilangan kata, penggantian, salah ucap, gejala keraguan, dan tersentak-sentak, sedangkan tiga indikator kekeliruan mengenal kata yang tidak ditampilkan oleh IAW, yaitu penyisipan, pembalikan, dan pengubahan tempat; (3) aspek kekeliruan memahami bacaan. Berdasarkan hasil observasi diperoleh informasi bahwa tiga indikator dalam aspek/dimensi kekeliruan memahami bacaan semua ditampilkan oleh IAW. Artinya bahwa IAW mengalami kesulitan belajar membaca yang diwujudkan dengan kekeliruan memahami bacaan dalam semua indikator. Tiga indikator kekeliruan memahami bacaan yang ditampilkan oleh IAW sebagaimana ditampilkan oleh FS dan WDP ketika belajar membaca adalah banyak keliru menjawab pertanyaan dari bacaan, tidak dapat mengemukakan urutan cerita yang dibaca, tidak paham tema utama dari cerita isi bacaan; serta (4) aspek gejala serbaneka. Berdasarkan hasil observasi diperoleh informasi bahwa tiga indikator dalam aspek/dimensi serbaneka semua ditampilkan oleh IAW. Artinya bahwa IAW mengalami kesulitan belajar membaca yang diwujudkan dengan kekeliruan serbaneka dalam semua indikator. Tiga indikator serbaneka yang ditampilkan oleh IAW sebagaimana juga ditampilkan oleh FS dan WDP ketika belajar membaca adalah membaca kata demi kata, membaca dengan penuh ketegangan dan nada tinggi, dan membaca dengan penekanan yang tidak tepat.

Persamaan dan perbedaan karakteristik bentuk kesulitan belajar membaca

Berdasarkan uraian di atas, nampaknya ada persamaan dan perbedaan karakteristik pada masingmasing bentuk kesulitan belajar membaca yang dihadapi oleh ketiga siswa tersebut. Berikut disajikan persamaan dan perbedaan karakteristik bentukbentuk kesulitan belajar membaca pada tabel 1 .

Tabel 1

Persamaan Karakteristik Bentuk Kesulitan Belajar Membaca Pada Ketiga Siswa

\begin{tabular}{|c|c|c|c|}
\hline No & $\begin{array}{l}\text { Betuk Kesulitan Belajar } \\
\text { Membaca }\end{array}$ & Karakteristik yang sama & Ket \\
\hline 1 & $\begin{array}{l}\text { Kebiasaan membaca } \\
\text { yang tidak wajar }\end{array}$ & $\begin{array}{l}\text { (a) melawan guru } \\
\text { (b) terjadi pengulangan dalam membaca }\end{array}$ & $\begin{array}{l}\text { TP } \\
\text { SS }\end{array}$ \\
\hline 2 & $\begin{array}{l}\text { Kekeliruan mengenal } \\
\text { kata }\end{array}$ & $\begin{array}{l}\text { (a) penghilangan kata } \\
\text { (b) penggantian } \\
\text { (c) salah ucap } \\
\text { (d) gejala keraguan } \\
\text { (e) tersentak-sentak }\end{array}$ & $\begin{array}{l}\text { Ya } \\
\text { Ya } \\
\text { Ya } \\
\text { Ya } \\
\text { Ya }\end{array}$ \\
\hline 3 & $\begin{array}{l}\text { Kekeliruan memahami } \\
\text { bacaan }\end{array}$ & $\begin{array}{l}\text { (a) banyak keliru menjawab pertanyaan } \\
\text { dari bacaan. } \\
\text { (b) tidak dapat mengemukakan urutan } \\
\text { cerita yang dibaca } \\
\text { (c) tidak paham tema utama dari cerita } \\
\text { isi bacaan }\end{array}$ & $\begin{array}{l}\text { Ya } \\
\text { Ya } \\
\text { Ya }\end{array}$ \\
\hline
\end{tabular}

\begin{tabular}{|c|c|c|c|}
\hline No & $\begin{array}{c}\text { Betuk Kesulitan Belajar } \\
\text { Membaca }\end{array}$ & Karakteristik yang sama & Ket \\
\hline 4 & Gejala serbaneka & $\begin{array}{l}\text { (a) membaca kata demi kata } \\
\text { (b) membaca dengan penuh ketegangan } \\
\text { dan nada tinggi } \\
\text { (c) membaca dengan penekanan yang } \\
\text { tidak tepat }\end{array}$ & $\begin{array}{l}\mathrm{Ya} \\
\mathrm{Ya} \\
\mathrm{Ya}\end{array}$ \\
\hline
\end{tabular}

Keterangan:

TP : Tidak Pernah

SS : Sangat Sering

Informasi pada tabel 1 di atas secara jelas menggambarkan bahwa terdapat persamaan dalam beberapa karakteristik/indikator pada setiap bentuk kesulitan belajar membaca yang ditampilkan oleh ketiga siswa yang mengalami kesulitan belajar membaca. Hasil identifikasi terhadap ketiga siswa tersebut menunjukkkan bahwa pada karakteristik/ indikator di atas, ketiga siswa menampilkan karakteristik kesulitan yang sama.

Pada kesulitan belajar membaca bentuk kebiasaan membaca yang tidak wajar ada dua karakteristik/indikator kesulitan yang sama yang dihadapi oleh ketiga siswa yaitu melawan guru dalam kategori tidak pernah (TP), dan terjadi pengulangan dalam membaca dalam kategori sangat sering (SS). Pada bentuk kesulitan kekeliruan mengenal kata terdapat lima karakteristik kesulitan yang sama yang dihadapi oleh ketiga siswa yaitu penghilangan kata, penggantian, salah ucap, gejala keraguan, dan tersentak-sentak. Untuk bentuk kesulitan belajar membaca kekeliruan memahami bacaan, terdapat tiga karakteristik kesulitan yang sama yaitu banyak keliru menjawab pertanyaan dari bacaan, tidak dapat mengemukakan urutan cerita yang dibaca, serta tidak paham tema utama dari cerita isi bacaan.

Adapun pada bentuk kesulitan membaca gejala serbaneka terdapat tiga karakteristik kesulitan yang sama yang dihadapi oleh ketiga siswa yaitu membaca kata demi kata, membaca dengan penuh ketegangan dan nada tinggi, membaca dengan penekanan yang tidak tepat, sedangkan perbedaan karakteristik pada masing-masing bentuk kesulitan belajar membaca yang dihadapi oleh ketiga siswa disajikan dalam tabel 2.

Tabel 2

Perbedaan Karakteristik Bentuk Kesulitan Belajar Membaca Pada Ketiga Siswa

\begin{tabular}{|c|c|c|c|c|c|}
\hline No & $\begin{array}{l}\text { Betuk Kesulitan } \\
\text { Belajar Membaca }\end{array}$ & Karakteristik yang Berbeda & FS & WDP & IAW \\
\hline \multirow[t]{7}{*}{1} & Ke bi a s a a n & (a) mengernyitkan kening & SS & $\mathrm{S}$ & $\mathrm{S}$ \\
\hline & membaca yang & (b) gelisah & SS & KK & KK \\
\hline & tidak wajar & (c) irama suara meninggi & SS & $\mathrm{s}$ & SS \\
\hline & & (d) menggigit bibir & SS & $\mathrm{J}$ & $\mathrm{s}$ \\
\hline & & (e) menolak untuk membaca & $\mathrm{s}$ & KK & $\mathrm{J}$ \\
\hline & & $\begin{array}{l}\text { (f) menangis ketika disuruh } \\
\text { membaca }\end{array}$ & $\mathrm{J}$ & $\mathrm{TP}$ & TP \\
\hline & & $\begin{array}{l}\text { (g) ada baris yang terlompat/ } \\
\text { tidak dibaca }\end{array}$ & SS & KK & SS \\
\hline
\end{tabular}




\begin{tabular}{cclccc}
\hline No & $\begin{array}{c}\text { Betuk Kesulitan } \\
\text { Belajar Membaca }\end{array}$ & Karakteristik yang Berbeda & FS & WDP & IAW \\
\hline \multirow{5}{*}{$\begin{array}{l}\text { (h) menggerakkan kepala ke } \\
\text { kiri atau ke kanan } \\
\text { (i) meletakkan kepala pada } \\
\text { buku }\end{array}$} & SS & SS & KK & SS \\
& $\begin{array}{l}\text { (j) jarak mata dan buku kurang } \\
\text { dari 37,5 cm }\end{array}$ & SS & S & S \\
& Ke ke lir u a n & (a) penyisipan & Ya & Ya & Tdk \\
mengenal kata & (b) pembalikan & Ya & Tdk & Tdk \\
& (c) pengubahan tempat & Ya & Tdk & Tdk \\
\hline
\end{tabular}

Keterangan:

$\begin{aligned} \mathrm{SS} & =\text { Sangat Sering } \\ \mathrm{S} & =\text { Sering } \\ \mathrm{KK} & =\text { Kadang-Kadang } \\ \mathrm{J} & =\text { Jarang } \\ \mathrm{TP} & =\text { Tidak Pernah }\end{aligned}$

Berdasarkan tabel 2 di atas, dari empat bentuk kesulitan belajar membaca, ada dua bentuk kesulitan yang memiliki tampilan karakteristik yang berbeda yaitu kebiasaan membaca yang tidak wajar, dan kekeliruan mengenal kata, sedangkan bentuk kesulitan membaca kekeliruan memahami bacaan dan gejala serbaneka menunjukkan tidak ada karakteristik yang berbeda, serta semua karakteristiknya menunjukkan tampilan yang sama.

Pada bentuk kesulitan belajar membaca, kebiasaan belajar membaca yang tidak wajar, karakteristik yang ditampilkan oleh ketiga siswa menunjukkan variasi yang sangat tinggi. Di mana dari 12 karakteristik/indikator, terdapat sepuluh indikator/karakteristik yang tampil dalam intensitas sangat berbeda, yaitu ada yang sangat sering, sering, kadang-kadang, jarang, dan bahkan ada yang tidak pernah muncul sebagai salah satu indikator/ karakteristik kesulitan belajar membaca pada siswa tertentu; sebagai contoh karakteristik menolak untuk membaca, pada konteks FS menjadi sesuatu yang Sering ditampilkan, untuk WDP kategori KadangKadang, sedangkan pada IAW Jarang.

Demikian juga, pada kesulitan belajar membaca dalam bentuk kekeliruan mengenal kata, menunjukkan variasi karakteristik/indikator. Untuk FS, tiga karakteristik yang berbeda tersebut menjadi karakteristik yang ditampilkan, dimana dari tiga karakteristik yang berbeda menunjukkan variasi.

Adapun pada bentuk kekeliruan memahami bacaan dan gejala serbaneka, seluruh karakteristiknya tidak ada yang berbeda. Artinya bahwa tiga siswa tersebut mengalami kesulitan belajar membaca dalam karakteristik yang sama untuk dua bentuk kesulitan belajar membaca tersebut.

\section{Pembahasan}

Dengan mendasarkan kepada hasil analisis dan uraian di atas, bahwa tiga siswa yang menjadi sasaran riset menunjukkan karakteristik siswa yang mengalami kesulitan belajar membaca. Karakteristikkarakteristik tersebut tersebar dalam empat bentuk/ dimensi kesulitan belajar membaca yaitu kebiasaan membaca yang tidak wajar, kekeliruan mengenal kata, kekeliruan memahami bacaan, dan gejala serbaneka.

Penting ditekankan di sini bahwa tidak semua karakteristik/indikator kesulitan belajar membaca yang ada pada empat bentuk/dimensi kesulitan belajar membaca sebagaimana di atas pada saat observasi ditemukan/ditampilkan oleh setiap anak. Artinya bahwa ada keragaman atau perbedaan tingkat kesulitan belajar membaca yang dihadapi oleh masingmasing siswa tersebut. Semakin banyak karakteristik/ indikator kesulitan belajar membaca yang ditampilkan oleh siswa menunjukkan tingginya tingkat kesulitan belajar membaca yang dihadapi oleh siswa tersebut.

Perbedaan karakteristik atau tingkat problem atau kesulitan membaca yang dihadapi oleh masingmasing siswa berimplikasi pada berbedanya metode pembelajaran membaca yang semestinya diterapkan pada saat memberikan remediasi. Oleh karena itu, pemberian remediasi bersifat individual karena berbasiskan kepada karakteristik dan tingkat kesulitan yang dihadapi oleh setiap siswa. Dengan pemberian remidiasi yang bersifat personal, dimungkinkan akan terjadi akselerasi kemampuan membaca pada anak yang mengalami kesulitan belajar membaca.

Temuan hasil kajian lapangan ini sejalan dengan hasil wawancara dengan guru kelas II yang menyatakan bahwa tiga siswa tersebut termasuk kategori siswa yang sulit dalam membaca. Hal ini juga diperkuat oleh catatan yang diberikan oleh guru kelas dalam rapor, dimana diantara catatan yang selalu diberikan oleh guru adalah terkait dengan dorongan untuk terus belajar membaca. Catatan pada rapor tersebut, mengindikasikan bahwa secara kualitatif, guru berpandangan rendahnya hasil belajar disebabkan karena ada problem/kesulitan dalam membaca sebagai pintu gerbangnya pengetahuan.

Secara teoretis, kesulitan belajar membaca akan berakibat pada rendahnya hasil belajar yang diperoleh siswa yang mengalami kesulitan belajar membaca. Kondisi ini tampak secara nyata dialami oleh tiga siswa tersebut. Hasil belajar tiga siswa tersebut selalu berada di bawah rata-rata kelas dan berkecenderungan pada setiap semesternya selalu ada mata pelajaran yang tidak mencapai KKM. Oleh karena rendahnya hasil belajar yang diperoleh, tiga siswa tersebut pernah mengalami tinggal kelas; misalnya FS tidak naik kelas di kelas II, WDP pernah tidak naik kelas pada kelas I, dan khusus IAW bahkan dua kali tidak naik kelas 
yakni pada kelas I dan kelas II (pada saat penelitian ini dilaksanakan IAW tidak naik ke kelas III), dengan demikian pada setiap kelas IAW menempuhnya selama dua tahun. Kondisi ini memperkuat hasil kajian para pakar sebelumnya bahwa kesulitan belajar membaca akan berakibat pada rendahnya hasil belajar secara umum dan akan berakibat pada kegagalan studinya (Morris dkk, 2000; Abdurrahman, 2003; Jamaris, 2009).

\section{PENUTUP}

\section{Kesimpulan}

Berdasarkan hasil penelitian di atas, dapat ditarik beberapa kesimpulan sebagai berikut (1) kondisi kesulitan belajar membaca yang dialami siswa sesungguhnya telah nampak semenjak kelas I dan terus berlanjut sampai di kelas II, serta dimungkinkan akan terus terjadi pada kelas/tahun berikutnya jika tidak dilakukan kegiatan remediasi membaca dengan metode yang tepat sesuai dengan karakteristik kesulitan membaca yang dihadapi oleh siswa; (2) kesulitan belajar membaca yang dihadapi oleh siswa tampil dalam empat bentuk yaitu kebiasaan membaca yang tidak wajar, kekeliruan mengenal kata, kekeliruan memahami bacaan, dan gejala serbaneka; (3) masingmasing siswa menunjukkan karakteristik kesulitan membaca yang berbeda-beda. Perbedaan tersebut nampak pada karakteristik kesulitan yang berbeda pada dimensi atau bentuk kesulitan belajar membaca meskipun pada dimensi atau bentuk kesulitan yang lain menunjukkan kesamaan karakteristik kesulitan yang dihadapi; serta (4) siswa yang mengalami kesulitan belajar membaca menunjukkan hasil belajar yang rendah pada mata pelajaran-mata pelajaran yang lain. Artinya, bahwa kesulitan belajar membaca berhubungan dengan rendahnya hasil belajar siswa pada mata pelajaran yang lain; dan (5) terdapat bentuk atau dimensi kesulitan belajar membaca yang memiliki kecenderungan paling dominan sama dihadapi oleh semua siswa, yaitu kekeliruan memahami bacaan dan gejala serbaneka.

\section{Saran}

Berdasarkan temuan penelitian di atas, peneliti mengajukan beberapa saran sebagai berikut (1) kepada Kementerian Pendidikan dan Kebudayaan, (a) untuk membuat kebijakan pengadaan dan penempatan pendidik/ahli pendidikan khusus di sekolah dasar, (b) agar dapat menggalakkan program kegiatan identifikasi dan remediasi terhadap anak didik yang disinyalir mengalami kesulitan belajar membaca, (c) untuk memfasilitasi pelibatan dan kerja sama lintas disiplin ilmu dan keahlian dalam penanganan siswa berkesulitan membaca, seperti pelibatan ahli pendidikan khusus, dokter atau tenaga medis terkait, ahli gizi, dan psikolog; (2) kepada kepala sekolah dasar, (a) untuk mendorong dan memfasilitasi para guru untuk melakukan identifikasi dan remediasi membaca terhadap siswa yang mengalami kesulitan belajar membaca, (b) menyediakan ruangan khusus untuk remediasi/penanganan kesulitan belajar membaca. Ruang tersebut dapat dipergunakan oleh guru kelas dan guru khusus untuk mengkaji dan menangani berbagai problem belajar yang terjadi pada siswa, diantaranya problem terkait kesulitan belajar membaca; (3) kepada guru sekolah dasar, (a) untuk membekali diri tentang kemampuan teoretis dan praktik identifikasi dan remediasi bagi siswa berkesulitan belajar membaca, (b) untuk melakukan assesment dan identifikasi terhadap kemampuan membaca siswa dan melakukan remediasi sejak dini terhadap anak didik yang berkesulitan membaca, (c) program kegiatan remediasi harus berdasarkan kepada hasil identifikasi yang cermat, dan (d) remediasi atau treatment yang diberikan kepada anak yang mengalami kesulitan belajar membaca harus mempertimbangkan bentuk dan karakteristik kesulitan yang dihadapi oleh masing-masing anak, mengingat kesulitan yang dihadapi masing-masing anak berbeda.

\section{DAFTAR PUSTAKA}

Abdurrahman, M. (2003). Pendidikan bagi anak berkesulitan belajar. Jakarta: Depdikbud \& Rineka Cipta.

Delphie, B. (2006). Pembelajaran anak berkebutuhan khusus dalam setting pendidikan inklusi. Bandung: PT Refika Aditama.

Depdiknas. (2002). Keputusan Menteri Pendidikan Nasional Republik Indonesia Nomor 012/U/2002 tentang sistem penilaian di sekolah dasar, sekolah dasar luar biasa, sekolah luar biasa tingkat dasar, dan madrasah ibtidaiyah. Jakarta: Depdiknas.

Jamaris, M. (2009). Kesulitan belajar, perspektifassessmen dan penanggulangannya. Jakarta: Yayasan Pena Mas Murni.

Moleong, L. J. (1991). Metodologi penelitian kualitatif. Jakarta: Remaja Rosdakarya.

Morris, D., Tyner, B., \& Perney, J. (2000). Early steps: Replicating the effects of a first-grade intervention program. Journal of education psychology, 92(4), 681-693. doi: http:// psycnet.apa.org/ doi/10.1037/0022-0663.92.4.681

Kemdikbud. (2016). Peraturan Menteri Pendidikan Dan Kebudayaan Republik Indonesia Nomor 24 Tahun 
2016 tentang kompetensi inti dan kompetensi dasar pelajaran pada kurikulum 2013 pada pendidikan dasar dan pendidikan menengah. Jakarta: Kemdikbud.

Sandjaja, S. (1993). Hubungan antara persepsi visual dan tingkat pendidikan orang tua dengan kemampuan membaca di SD Kanisius Semarang Barat. Tesis tidak diterbitkan. Yogyakarta: Program Pascasarjana UGM.

Santrock, J.W. (1999). Life- span development. Boston: McGraw.

Somad, P. (2002). Bimbingan membaca bagi siswa berkesulitan membaca. Jurnal Jassi Anakku, 1(1). 38-51. 